\title{
REASONS FOR THE EXPERIMENTAL RESEARCH OF GAS OUTFLOWS BASED ON THE SIGNALS OF WEAK INTERACTIONS BETWEEN THE TESTED MODEL OF THE GAS PIPELINE, AND TESTED EQUALIZER
}

\section{PRZESŁANKI DO EKSPERYMENTALNEGO BADANIA WYPLYWÓW GAZU NA PODSTAWIE SYGNAŁÓW SŁABYCH INTERAKCJI MIECDZY BADANYM MODELEM GAZOCIĄGU, A BADANYM KOREKTOREM}

\author{
Grądzki Rafal $^{1}$, Golak Karol ${ }^{1}$, Lindstedt Pawel ${ }^{2}$, Bartoszewicz Błażej ${ }^{1}$ \\ ${ }^{(1)}$ Bialystok University of Technology, Poland \\ (2) Air Force Institute of Technology, Poland \\ e-mail: r.gradzki@pb.edu.pl; sekretariat.naukowy@itwl.pl
}

\begin{abstract}
This article applies diagnosing issues outflows of gas pipelines using specialized research equipment - equalizers. Variant with only two measuring devices (equalizers), arranged on the inlet and outlet of the pipeline, and the standard pressure transducers and flow rate were considered. The signals from the system and research equipment (equalizers) are the basis for the development of new method to test outflow of gas pipeline, which is based on the quotient of the power spectral density of signals generated by the equalizer (diagnoser) and signals measured using standard pressure transducers and flow rate. Possible use to analysis the signals power will allow go from signal diagnostic for more effective parametric diagnostic.
\end{abstract}

Keywords: gas pipeline, equalizer, diagnostic, power spectral density

Streszczenie: Artykut dotyczy zagadnień diagnozowania wycieków z gazociagów za pomoca dwóch specjalistycznych urządzeń badawczych - korektorów. Rozważany jest wariant tylko z dwoma urzadzeniami pomiarowymi (korektorami), rozmieszczonymi na wlocie $i$ wylocie rurociagu oraz zastosowaniu do pomiaru standardowych przetworników ciśnienia i natężenia przepływu. Generowane sygnały układu sa podstawa do opracowania nowej metody badania wycieku z gazociagu za pomoca ilorazu gęstości widmowej mocy sygnałów generowanych przez korektor (diagnozer) do sygnałów generowanych przez standardowe przetworniki. Wykorzystanie do analizy mocy sygnałów pozwoli przejść od diagnostyki sygnałowej do skuteczniejszej diagnostyki parametrycznej.

Stowa kluczowe: gazociag, korektor, diagnostyka, gęstość widmowa mocy 
Reasons for the experimental research of gas outflows based on the signals... Przesłanki do eksperymentalnego badania wypływów gazu na podstawie...

\section{Introduction}

Pipelines are large in size and complicated construction, and are therefore difficult to handle including for diagnostic purposes. The biggest problem in the diagnosis is identification and location of the outflow (especially when it is small). It turns out that the diagnostic of the gas pipeline is difficult and not sufficiently precise. This is caused by low diagnostic compliance resulting in a shortage of diagnostic information. Deficiencies in the efficiency of diagnosis, stems from multidimensional environment and the complex dynamics of the pressing process $[1,4 \div 6,8 \div 12,15 \div 17,19,21 \div 27,29 \div 31]$.

Current methods of outflow location are based on the measurement of flow parameters (pressure, flow) of the pumped medium at the beginning and end of the test section of the gas pipeline.

Such methods include:

- gradient method,

- correlation method,

- method based on tracking wave fronts of said expansion.

The disadvantage of these methods is the low sensitivity to outflow. Even after the application of a very complex calculation procedures in practice it is possible to identify only substantial outflows and locate them with coarse accuracy. This incomplete information is still very important to ensure proper handling of long pipelines.

Effective way to obtaining new diagnostic information, and thus improving diagnostic susceptibility and increase the efficiency diagnosing outflows from gas pipeline may be the use of the information coming from the weak interaction, caused by special measuring devices - equalizers, and the test object - the gas pipeline.

\section{The idea of the test stand and construction of the equalizer}

The test stand for gas leakages diagnostic from pipeline is presented in Figure 1. The test stand is made of thermo-welded polypropylene pipes (a). This tubes are mounted on a frame of aluminum profiles (b). At the beginning and end of the main line of the pipeline equalizers (c) will be attached using pipe tee for research leakages. At the beginning of the pipeline's there is the connection to the compressor (d) and the pressure vessel used to achieve adequate pressure in the station. In various distances from the beginning of the pipeline will be installed faucets (e) used to simulate leakages.

The total capacity of the pipeline can be increased by mounting the additional pressure vessel at any point on its length. 


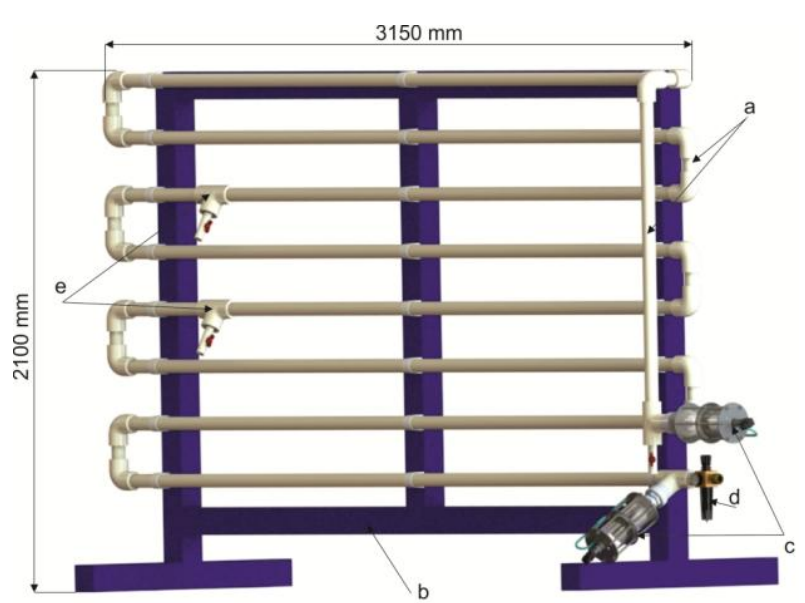

Fig. 1. The scheme of the test stand for researches of gas leakages with added equalizers, where: $a$-pipes, $b$-aluminium profiles, $c$-equalizers,

$$
d \text {-compressor, } e \text {-faucets; }
$$

In Fig. 2 an equalizer has been shown. It is used to cause the weak interaction between the it and the pipeline. It consists of two chambers separated by a changeable membrane $(a)$. Both chambers are filled with the same medium as the test pipeline and has the same pressure. In the middle of the axis of symmetry of the equalizer, on the membrane the adjustable mass $(b)$ was placed.

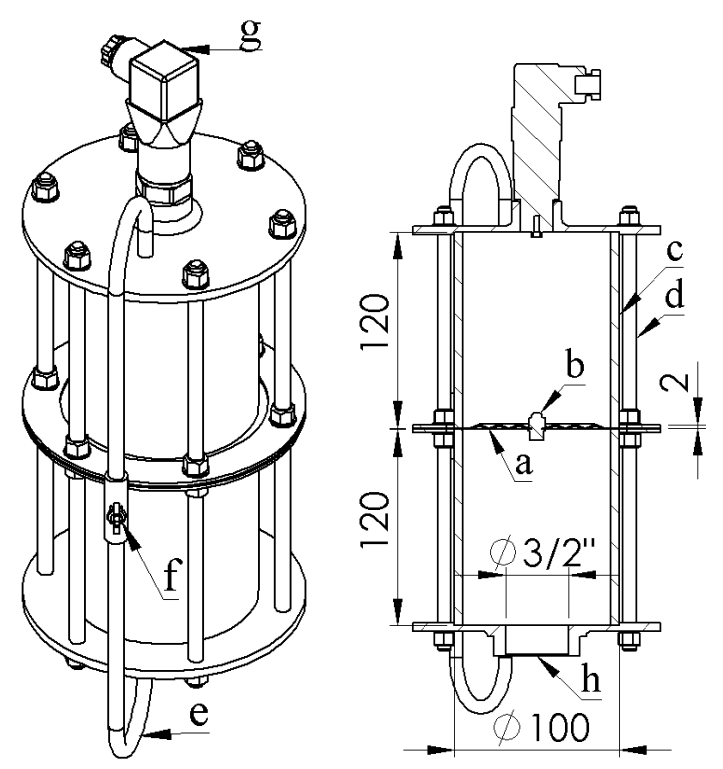

Fig. 2 Construction of an equalizer for the diagnosis of leakage from gas pipelines, where: a - removable membrane, $b$-adjustable mass, $c$ - tube walls, $d$-the pivots, $e$ - the pressure equalizing tube, $f$-valve on the equalizing tube, $g$-differential pressure sensor or mass displacement sensor, $h$-connection to the pipeline. 
Reasons for the experimental research of gas outflows based on the signals... Przesłanki do eksperymentalnego badania wypływów gazu na podstawie...

It is assumed that the observed motion of the mass will give us. The possibility to complete determination of the interaction between the equalizer and the pipeline for a variety conditions of the object (pipeline). Equalizers membrane and the weight placed thereon, are interchangeable, and there is the possibility of its selection (change the membrane type and mass weight) depending on the pressure in the system and the observed size of the leakage. The size of the chambers can be easily changed by exchanging length of the pipes forming the wall $(c)$ and length of pivots $(d)$.

Equalizers chambers are connected by a tube $(e)$ on which a valve for closing the flow $(f)$ is mounted. The pipe is for equalization of the pressures in both chambers (the test pipeline and all equalizers has equal pressure).

At the top of the equalizer can be mounted sensor $(g)$ measuring depending on the needs the pressure difference between the equalizer chambers, or the displacement of the mass caused by the leakage of gas from the pipeline.

On the opposite side of the equalizer there is a connection $(h)$ to attach it to the observed gas pipeline.

The membrane and the mass on it during uninterrupted operation of the pipeline are in equilibrium. As a result of the gas leakage, the pressure disturbances occured in the pipeline and equalizer, leading to the membrane and mass vibrations. These disorders may be registered both by the differential pressure sensor and the displacement sensor for mass which are mounted in the equalizer. These signals are used to diagnose leakages from gas pipelines.

\section{The theoretical basis of a new method of diagnosing the gas outflow of long pipelines}

The existing methods of diagnosis based on signals defined:

- in the domain (area) time " $t$ " is $p_{1}(t), m_{1}(t), m_{k l}(t), p_{2}(t), m_{2}(t), m k_{2}(t)[2,20,28]$.

- space domain , $\tau$ " of self and cross-correlation function: $R_{p l p l}, R_{p 2 p 2}, R_{m l m l}$,

$$
R_{m 2 m 2}, R_{m k 1 m k 1}, R_{p l p 2}, R_{m 1 m 2}, R_{m k 1 m k 2} \text { etc. }[2,3,28]
$$

where:

$p_{1}$ - the pressure at the beginning of the pipeline,

$m_{l}$ - mass flow rate at the beginning of the pipeline,

$m_{k 1}$ - mass flow rate of the equalizer at the beginning of the pipeline,

$p_{2}$ - pressure at the end of the pipeline,

$m_{2}$ - mass flow rate at the end of the pipeline,

$m_{k 2}$ - mass flow rate of the equalizer at the end of the pipeline, 
The proposed new method of diagnosing the gas pipeline also are used signals of weak interactions $m_{k 1}$ and $m_{k 2}$ witch are resulting from the operation of specialized investigated equalizers (diagnoser) specified in the domain of time shift $\tau$, and then in the frequency $\omega$.

Used here the opportunities arising from theory of signal processing $[3,7,14$, $15 \div 19$ ], which consists in determining the square amplitude amplification and time shift between any (determined by an expert) signals:

$$
\begin{gathered}
A_{m_{k 1} m_{k 2}}^{2}=\frac{S_{m_{k 1} m_{k 1}}}{S_{m_{k 2} m_{k 2}}} \\
\varphi_{m_{k 2} m_{k 1}}=\operatorname{Arg} \frac{S_{m_{k 2} m_{k 1}}}{S_{m_{k 2} m_{k 2}}}
\end{gathered}
$$

where:

$$
\begin{array}{ll}
A^{2} & \text { - square amplification amplitude signals } m_{k 1} \text { and } m_{k 2} \\
\varphi & \text { - phase shift signals } m_{k 1} \text { and } m_{k 2} ; \\
S_{m k l m k l} & \text { - autopower spectral density of signals } m_{k 1} \\
S_{m k 2 m k 2} & \text { - autopower spectral density of signals } m_{k 2} \\
S_{m k 2 m k 1} & \text { - autopower spectral density of signals } m_{k 1} \text { and } m_{k 2} ; \\
A r g & \text { - the argument of the spectral transfer function. }
\end{array}
$$

These formulas can also be used for other configurations measured signals $[7,13 \div 18,28]$.

a) configurations of diagnostic model $A^{2}$ :

$$
\begin{gathered}
A_{m_{1} m_{k 1}}^{2}=\frac{S_{m_{1} m_{1}}}{S_{m_{k 1} m_{k 1}}} \\
A_{m_{2} m_{k 2}}^{2}=\frac{S_{m_{2} m_{2}}}{S_{m_{k 2} m_{k 2}}} \\
A_{p_{1} m_{k 1}}^{2}=\frac{S_{p_{1} p_{1}}}{S_{m_{k 1} m_{k 1}}}
\end{gathered}
$$


Reasons for the experimental research of gas outflows based on the signals... Przesłanki do eksperymentalnego badania wypływów gazu na podstawie...

$$
\begin{gathered}
A_{p_{2} m_{k 2}}^{2}=\frac{S_{p_{2} p_{2}}}{S_{m_{k 2} m_{k 2}}} \\
A_{p_{1} m_{k 2}}^{2}=\frac{S_{p_{1} p_{1}}}{S_{m_{k 2} m_{k 2}}}
\end{gathered}
$$

b) the analogous formulas are for the model $\varphi$.

In case of application diagnostic method using the diagnostic model $\varphi$ (based on the cross -power spectral density of signals) is replaced much more configuration than the using the diagnostic model $A^{2}$ (based on its auto power density signals).

Additional benefits of using these methods of diagnosis are result from the transition of the indicator method (limited number of indicators) on parametric models of analysis of the measured signals. [7, 13 $\div 18]$

Then, the above diagnostic models obtained in parameterized form. For equation 1, 2 will be described as follows:

$$
\begin{gathered}
A_{m_{k 1} m_{k 2}}^{2}=\frac{S_{m_{k 1} m_{k 1}}}{S_{m_{k 2} m_{k 2}}}=\frac{A_{0}^{*}+A_{1}^{*} s+A_{2}^{*} s^{2}+\ldots+A_{n}^{*} s^{n}}{L_{0}^{*}+L_{1}^{*} s+L_{2}^{*} s^{2}+\ldots+L_{n}^{*} s^{n}} \\
\varphi_{m_{k 2} m_{k 1}}=\operatorname{Arg} \frac{S_{m_{k 2} m_{k 1}}}{S_{m_{k 2} m_{k 2}}}=\operatorname{Arg} \frac{B_{0}^{*}+B_{1}^{*} s+B_{2}^{*} s^{2}+\ldots+B_{n}^{*} s^{n}}{L_{0}^{*}+L_{1}^{*} s+L_{2}^{*} s^{2}+\ldots+L_{n}^{*} s^{n}}
\end{gathered}
$$

where:

$s \quad-$ complex variable, $s=j \omega$,

$A_{i}^{*}, \quad i=0,1, \ldots, n$ - estimate parameters of the power spectral density signals $m_{k l}$,

$B_{i}^{*}, \quad i=0,1, \ldots, n$ - estimate parameters of the cross-power spectral density signals $m_{k 1}$ and $m_{k 2}$,

$L_{i}^{*}, \quad i=0,1, \ldots, n$ - estimate parameters of the power spectral density signals $m_{k 2}$.

In the process of diagnostic inference is recommended to use normalized parameter values $A_{i}^{*}, B_{i}^{*}$ and $L_{i}^{*}$ obtained by subtracting the average parameter $\mu_{i}$ and dividing by the standard deviation $\sigma_{i}$. $[7,13 \div 18]$

On the basis of equation 8 to 9 , it can be expected that changes in model parameters $A^{2}$ and $\varphi$ will correspond to occurred of the gas pipeline leaks. 


\section{Conclusion}

The paper presents the concept laboratory stand to study outflow of gas from the long pipeline on the basis of a time - frequency analysis of signals from the built-in to them special equalizers. This concept positions based on the fact that between the test equalizer (diagnoser) and the tested working gas pipeline are occur weak interactions, and hence diagnostic signals which can be used to identify the location and size of the gas outflow.

The addition of special research equipment (equalizers) to the gas pipelines makes it possible to acquire valuable diagnostic information, which are weak interactions signals. In contrast to the standard pressure signals, the signals of weak interactions are more sensitive and resistant to interference. Use of weak interactions signals can constitute complement used co far flow and pressure flow signals.

Joining equalizers to gas pipelines does not affect the operation of the pipeline and is easy to implement.

The basis for the analysis of the measured signals are correlation functions (time) and power spectral density functions (frequency) auto and cross of the signals interaction between the research gas pipeline and equalizers, as well as between the applied equalizers (in the initial phase of the research will be a two equalizers with the same and different sizes). Used equalizers in the slightest cannot and do not affect the quality of the static and dynamic gas pipeline investigated.

In addition, crossing on a time - frequency signal analysis (through the use of a parameterized model $\mathrm{A}^{2}$ and $\varphi$ ) gives a much more possibilities than the use methods based on the quality objectives, which number is limited.

At work presented results confirm that properly selected and attached to the pipeline diagnosed equalizers, fulfilling the role of research objects, offer the possibility to obtaining valuable diagnostic information, allowing to improve their diagnostic susceptibility, and thus increase the effectiveness of their diagnosis.

\section{Literature}

[1] Apostoloudia A. Douka E. Hadjileontiadis L. J. Rekanos I. T. Trochidis A.: Time-frequency analysis of transient dispersive waves, Applied Acoustics, vol. 68, no. 3,2007, pp. 296-309.

[2] Bendat J.S. Piersol A.G.: Metody analizy i pomiaru sygnałów losowych, PWN, Warszawa 1976.

[3] Bracewell R.: Przekształcenie Fouriera i jego zastosowania, Wydawnictwo Naukowo Techniczne 1968.

[4] Colombo A. F. Lee P. Karney B. W.: A selective literature review of transientbased leak detection methods, Journal of Hydro-Environment Research, vol. 2, no. 4, 2009, pp. 212-227. 
Reasons for the experimental research of gas outflows based on the signals... Przesłanki do eksperymentalnego badania wypływów gazu na podstawie...

[5] Ferrante M. Brunone B.: Pipe system diagnosis and leak detection by unsteady-state tests. 2. Wavelet analysis, Advances in Water Resources, vol. 26, no. 1, 2003, pp. 107-116.

[6] Ghazali M. F. Beck S. B. M. Shucksmith J. D. Boxall J. B. Staszewski W. J.: Comparative study of instantaneous frequency based methods for leak detection in pipeline networks, Mechanical Systems and Signal Processing, vol. 29, 2012, pp. 187-200.

[7] Grądzki R. Lindstedt P. Golak K.: Koncepcja stanowiska laboratoryjnego do badania wypływu gazu $\mathrm{z}$ długich gazociągów na podstawie czasowoczęstotliwościowej analizy sygnałów $\mathrm{z}$ wbudowanych do nich specjalistycznych korektorów, Studia i Materiały Polskiego Stowarzyszenia Zarządzania Wiedzą, Nr 68 (2014), pp.103-112.

[8] Hao J. Zhang L. Wei L. Ding Q.: Integrated leakage detection and localization model for gas pipelines based on the acoustic wave method, Journal of Loss Prevention in the Process Industries, vol. 27 2014, pp. 74-88.

[9] Kowalczuk Z. Gunawickrama K.: Detekcja i lokalizacja wycieków w rurociągach przesyłowych. Rozdział 21 pracy zbiorowej pod red. J. Korbicza, J. Kościelnego, Z. Kowalczuka i W. Cholewy: Diagnostyka procesów. Modele, metody sztucznej inteligencji, zastosowania, Warszawa, WNT, 2002.

[10] Laurentys C. A. Bomfim C. H. M Menezes B. R. Caminhas W. M.: Design of a pipeline leakage detection using expert system: A novel approach, Journal Applied Soft Computing, vol 11 Issue 1, 2011, pp. 1057-1066.

[11] Lee P. J. Vítkovský J. P. Lambert M. F. Simpson A. R. and. Liggett J. A.: Frequency domain analysis for detecting pipeline leaks, Journal of Hydraulic Engineering, vol. 131, 2005, no. 7, pp. 596-604.

[12] Li S. Wen Y. Li P. Yang J.: Leak location in gas pipelines using crosstimefrequency spectrum of leakage-induced acoustic vibrations, Journal of Sound and Vibration, vol. 333, no. 17, 2014, pp. 3889-3903.

[13] Lindstedt P. Grądzki R.: Model for blade diagnosis in a working rotor machine employing the method of virtual elimination of stochastic environment. Archive of Mechanical Engineering, Vol. 58, nr 3, 2011, pp. 305-318.

[14] Lindstedt P., Kotowski A.: Basics for innovations in vibroacoustic diagnostics of transport machines rotor blades, Archives of Transport. Vol. 16, $\mathrm{nr} 4,2004$, pp. 47-61.

[15] Lindstedt P.: Praktyczna diagnostyka maszyn i jej teoretyczne podstawy, Wydawnictwo Naukowe ASKON, Warszawa 2002.

[16] Lindstedt P.: Słabe interakcje w procesie diagnozowania wycieków z układów hydraulicznych, Prace naukowe ITWL, zeszyt nr 10 2000, pp. 19-31. 
[17] Lindstedt P.: The method of complex worthiness assessment of an engineering object in the process of its use and service, Solid State Phenomena, vol. 144/2009, Trans Tech Publications, pp. 45-52.

[18] Lindstedt P.: Weak interactions between objects in the signal-based and parametric diagnostics of transport-dedicated complex engineering systems, Aircraft Engineering and Aerospace Technology Vol.77, nr 3, 2005, pp. 222-227.

[19] Liu P.T. Gong R.K. Gong Y.H. Wang C.H.: A Gas Pipeline Leakage Diagnosis of Fusing BP Neural Network Basing on WSN and D-S Theory. Applied Mechanics and Materials 2014, V. 541-542, pp. 1442-1446.

[20] Niederliński A.: Systemy komputerowe automatyki przemysłowej , T2 Zastosowania, WNT, Warszawa 1985.

[21] Ostapkowicz P: Signals of weak interobject interactions in diagnosing of lekages from pipelines, Eksploatacja i niezawodność, nr 33, 1/2007, pp. 31-45.

[22] Ostapkowicz P: Sygnały słabych interakcji międzyobiektowych w diagnostyce wycieków z rurociągów. Rozdział w pracy zbiorowej pod red. J. Korbicza, K. Patana, M. Kowala: Diagnostyka procesów i systemów, Warszawa, Wydaw. EXIT, 2007, pp. 323-330.

[23] Ostapkowicz P: Leakage detection from liquid transmission pipelines using improved pressure wave technique. Eksploatacja i Niezawodność = Maintenance and Reliability Vol. 16, nr 1 (2014) pp. 9-16.

[24] Rajtar J. M. Muthiah R.: Pipeline leak detection system for oil and gas flowlines, Journal of Manufacturing Science and Engineering, Transactions of the ASME, vol. 119,1997, no. 1, pp. 105-109.

[25] Rashid S. Qaisar S. Saeed H. Felemban E.: Performance analysis of leak detection algorithm in long range pipeline networks using transform analysis, Proceedings of the IEEE Conference on Systems, Process and Control (ICSPC '13), pp. 10-15.

[26] Saeed H. Ali S. Rashid S. Qaisar S. Felemban E.: Reliable monitoring of oil and gas pipelines using wireless sensor network (WSN), Proceedings of the IEEE 9th International System of Systems Engineering Conference, 2014.

[27] Sobczak R: Lokalizacja nieszczelności w rurociągach metodą śledzenia czół fal ciśnienia, Przemysł Chemiczny, nr 83, 6/2004, pp. 296-299.

[28] Szabatin J.: Podstawy teorii sygnałów, WKŁ Warszawa 2000.

[29] Tomasik P.: Zastosowania modeli dokładnych sieci do detekcji i lokalizacji wycieków, Diagnostics of Processes and Systems, 2011, pp. 507-512.

[30] Yang Z. Liu M. Shao M. Ji Y.: Research on Leakage Detection and Analysis of Leakage Point in the Gas Pipeline System, Open Journal of Safety Science and Technology Vol.1 No.3, Pub. Date: December 30, 2011, pp. 94-100. 
Reasons for the experimental research of gas outflows based on the signals... Przestanki do eksperymentalnego badania wypływów gazu na podstawie...

[31] Zhang J: Statistical pipeline leak detection for all operating conditions, Pipeline \& Gas Journal, February 2001, pp. 42-45.

\section{This paper was supported by the Bialystok University of Technology under the research project No. S/WM/1/2012.}

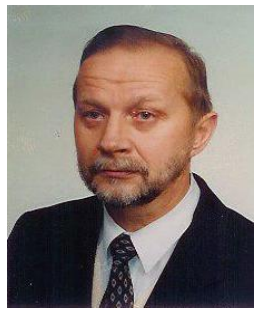

Prof. dr hab. inz Pawel Lindstedt, professor of the Bialystok University of Technology, associate professor of the Air Force Technical Institute. Research subjects: Construction and utilisation of machines, applied automatics, diagnostics and reliability of machines. His works concern diagnostics of aircraft engines, hydraulic systems, and bearing systems with functional, vibroacoustic and wear methods.

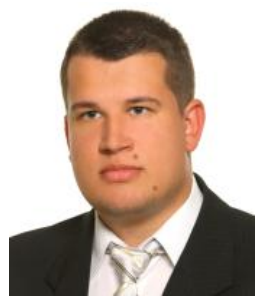

Dr inz. Rafat Gradzki Assistant Professorof the Faculty of Mechanical Engineering at the Bialystok University of Technology. Research subjects: technical diagnostics of bus engines, examination of potential reliability and safety level demonstrated by technical objects.

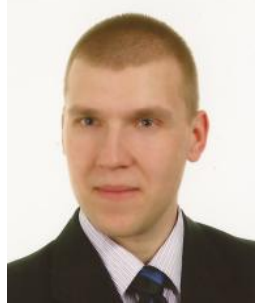

M. Sc. Eng. Karol Golak, PhD student of the Department of Mechanical Engineering at the Bialystok Technical University. Research subject: technical diagnostics of turbojet engine and gas pipelines, reliability and control of mechanical objects.

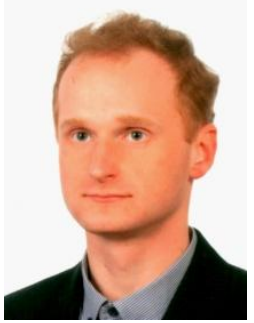

M.Sc. Eng. Btażej Bartoszewicz PhD student in a scientific discipline of Construction and Exploitation of Machines at the Faculty of Mechanical Engineering at the Bialystok University of Technology. Research subject: damage detection of rotating machinery using signal methods. 